\title{
MULTIDIMENSIONS OF POVERTY FOR AGRICULTURAL COMMUNITY IN TURKEY: KONYA PROVINCE CASE
}

\author{
Mustafa Kan ${ }^{1, *}$, Cennet Oguz $^{2}$, Arzu Kan ${ }^{1}$, Huseyin Ergun ${ }^{3}$ and Emel Demiroz ${ }^{4}$ \\ ${ }^{1}$ Ahi Evran University, Agricultural Faculty, Department of Agricultural Economics, Kurşehir-Turkey; ${ }^{2}$ Selcuk \\ University, Agricultural Faculty, Department of Agricultural Economics, Konya-Turkey; ${ }^{3}$ General Secretary, KTO \\ Karatay University, Konya-Turkey; ${ }^{4}$ Konya Commodity Exchange, Konya-Turkey \\ "Corresponding author’s e-mail: mustafa.kan@ahievran.edu.tr, mustafakan@gmail.com
}

\begin{abstract}
Poverty is a multi-dimensional global phenomenon. It encompasses health, housing, education, and social exclusion as well as simple incomes and expenditures. Multidimensional poverty is currently at the heart of many theoretical, empirical and institutional debates. The study was carried out in a rural settlement of Konya province in Turkey to determine the rural population's poverty structure and to quantify different general characteristics of both the poor and non-poor population according to the poverty line (relative poverty based household income-monetary approach) and asset based wealth index approach. The results showed that, there was strong similarity between the income based approach and asset based wealth index approach for most factors. The source of income for the people in the study area was from non-agricultural sector and the material deprivation is also an important factor for wealth. It was found that non-agricultural income was higher in the wealth group (75-100\%) than the other groups under study. The poor and low income households have high number of animals. These kinds of enterprises were mostly located in the high altitude areas which were not appropriate for crop production. It can be concluded in the light of investigated results that poverty is more prevalent in harsh geographical locations.
\end{abstract}

Keywords: Poverty, wealth index, agriculture sector, economic phenomenon, welfare indicator, household well-being.

\section{INTRODUCTION}

It is not mostly possible to explain the economic phenomenon of the modern world with the four main production factors, labor, capital, enterprise, and natural resources, taking place in classical economic theory (Karagul and Masca, 2005). Industrial societies cannot be based on physical capital accumulation only, rather other factors are also needed at the same time. In the new internal growth theories, every kind of physical, non-physical, political, organizational, environmental, intellectual, cultural, human, scientific, technological, and social elements, which directly or indirectly contribute to economic development and growth are accepted as capital (Berber, 2004). This approach showed itself in the studies of poverty like Thorbecke (2008), Cohen (2009), Ravallion (2010), Ravallion (2011), Alkire and Seth (2013), Bijaya et al. (2015) and UNDP (2016). In 1950s, welfare and happiness of people in economic meaning was measured by the rate of Gross Domestic Product (GDP) growth, because according to this view, if there is growth in a country, the income created in turn reached to the poor people as well. In the 1960s, national income per capita was used as the main welfare indicator. While, in the 1970s, meeting human main needs was accepted as the most important element of the welfare. In the 1980s, income per capita as well as non-monetary factors were also used in the measurement of human welfare (Sumner, 2004). The 1990s saw further development of the poverty concept. The idea of well-being came to act as a metaphor for absence of poverty, with concomitant emphasis on how poor people themselves view their situation. At the same time, inspired by Amartya Sen (Sen, 1985), UNDP developed the idea of human development: 'the denial of opportunities and choices to lead a long, healthy, creative life and to enjoy a decent standard of living, freedom, dignity, self-esteem and the respect of others...' (Maxwell, 1999). In the 2000s, universal rights and freedoms stood out (Sumner, 2004). More recently, in 2015, countries adopted the 2030 Agenda for Sustainable Development and its 17 Sustainable Development Goals (SDG's). It has been the greatest step taken for overcoming human poverty (UN, 2016).

It is widely accepted that human welfare is multidimensional and there have been numerous studies carried out in recent years that have measured for welfare (or poverty) in a multidimensional way. The indices, published in the report of Human Development Paradigm and Human Developments, developed by the United Nations Development Program, provide the development of this approach. Additionally, the Multidimensional Poverty Index (UN-MPI), first published by the United Nations in 2010, besides measuring poverty using monetary methods also attempted to introduce the deprivations of households using indicators such as health, education, and life standards to eliminate the deficiency (Alkire and Santos, 2010; Alkire et al., 2011; UNDP, 2016). 
Poverty is more than a lack of money. Poverty is multidimensional: it encompasses health, housing, education, and social exclusion as well as simple incomes and expenditures. Income (or economic growth), even if accurately measured, does not provide a reliable proxy measure of povertymultidimensional assessment is a superior alternative (Hicks and Streeten, 1979; Streeten et al., 1981; Sen, 2000; Bourguignon and Chakravarty, 2003; Sullivan, 2006). This assessment has been taken up by governments, who created measures of multiple dimensions of deprivation and there are numerous examples of new measurement methodologies in modern academic literature (Tsui, 2002; Atkinson, 2003; Bourguignon and Chakravarty, 2003; Deutsch and Silber, 2005; Duclos et al., 2006; Chakravarty and D'Ambrosio, 2006; Thorbecke, 2008; Ravallion, 2010; Ravallion, 2011, Alkire and Seth, 2012; Bijaya et al., 2015). The Human Development Paradigm developed by The United Nations Development Programme and the indices published in the Human Development Report ensure the development of this approach. Moreover, first published in 2010 by the United Nations - Multidimensional Poverty Index (MPI) - has also tried to put forward the notion that deprivation of households with indicators including health, education and the living standards to resolve the lack of monetary methods of measuring poverty (UNDP, 2016b). Additionally, the International Fund for Agricultural Development (IFAD) developed a simple and innovative tool to help answer this question. Just as rural poverty is based on more than one factor, the tool - the Multidimensional Poverty Assessment Tool (MPAT) - combines 10 different indicators to create a "rural poverty dashboard." (IFAD, 2016)

Principle Component Analyses (PCA) "provides plausible and defensible weights for an index of assets to serve as a proxy for wealth" (Filmer and Pritchett, 2001). Asset-based measures depict an individual or a household's long-run economic status and do not necessarily account for short-term fluctuations in economic well-being or economic shocks on the other hand. So it can be expected that the income variables are correlated with the wealth measure. These two might tap different dimensions of economic well-being (Gasparini et al., 2008; Lora, 2008). Many other studies of economics and public policy have implemented and recommend the use of PCA for estimating wealth effects (Minujin and Hee Bang, 2002; McKenzie, 2005; Vyass and Kumaranayakei, 2006; Labonne et al., 2007).

Income distribution indicators are needed for not only the economic reasons but also to enable to make a good evaluation of the various social systems. Inequity and poverty on income distribution are one of the most serious problems of the world and the income distribution problems are started to appear not only just the economic but also the political and social problems anymore. With the studies on monitoring the income inequality variation, it has needed to produce data for new notions like "income poverty", "poverty of social opportunity" and "social exclusion" by reducing the income distribution problem to the poverty problem. In Turkey, since 2006, officially, Turkish Statistical Institute (TURKSTAT) has started to carry out "Income and Living Conditions Survey (SILC)", where the panel survey method is used, within the scope of the studies compliance with European Union (EU). The aim of the survey is to supply comparable data on income distribution, living conditions, social exclusion and relative poverty based on income. Until 2014, estimations are produced on the level of Turkey, urban, rural and SR Level-1 (12 Regions) from the annual cross-sectional data as well as estimations on the level of Turkey from results of panel data. The sample size of the survey has been increased gradually between 2011 and 2014 to produce estimates on the Level-2 (26 Regions) (TURKSTAT, 2015).

One of the way to measure multidimensional poverty is "material deprivation" approach. Material deprivation belongs to the approaches of multidimensional poverty, which were incorporated in the last decades in order to complement the purely monetary understanding of poverty (Israel and Spannagel, 2013). The concept of material derivation was first developed by Townsend (1987), for whom it referred to a lack of "the material standards of diet, clothing, housing, household facilities, working, environmental and locational conditions and facilities which are orderly available in their society". In Turkey material deprivation rates were updated according to Eurostat arrangements for 2006-2014 (TURKSTAT, 2015). Except material deprivation index, UNDP MPI was declared in HDI 2013 finally. After that it is not possible to find official declaration in terms of multidimensional poverty. It means that there is need to study different dimension of poverty and their interactions each other.

The other thing is the situation of poverty in different areas. According to IFAD (2011) report that at least 70 per cent of the world's ultra-marginal poor people are in rural area, and a large proportion of the poor and hungry are children and young people. In developing countries, like Turkey, poverty is more prevalent in rural areas in comparison to urban areas, because a big part of rural population relies on agriculture and the reliability of the income supplied by agriculture (Ozturk, 2008). In fact, this is one of the leading problems, needed to be solved for Turkey of which population lives in the rural area at the ratio of about 23\% (TURKSTAT, 2012). In Turkey, the rural population rate is considerably low as compared to the urban population but much of the population in rural areas face higher levels of poverty. According to results the study carried out by TURKSTAT, the poverty rate in Turkey was $15 \%$ and the poverty rate in urban areas was $13.6 \%$ and $14.3 \%$ in rural areas (TURKSTAT, 2014). This rate reveals that poor people in Turkey that live in rural areas is more prevalent. However, there is no clear answer to the question how much income is turned into the household wellbeing. It means that in Turkey, there is a need special studies 
focusing on all dimensions of poverty in rural areas, not only income and/or expenditure based poverty approaches.

The study is important one showing the situation of agricultural community in rural areas of Turkey. The province of Konya, in which the study is carried out, is located in the south of Central Anatolia Region in the middle of Anatolian Peninsula. It is one of the five provinces with the largest rural population and the importance of rural population continuously maintained by years. In the year 2012, the rate of rural population to urban population of Konya Province was $31.23 \%$ (MEVKA, 2016; TURKSTAT, 2016). Konya province is also important place to represent the agriculture community in Turkey. $46.81 \%$ of Konya province's land consists of agricultural land. Konya ranks first in total agricultural land and production of barley, wheat, sugar beet, sunflower, tulip, cherry, dried beans, and carrot in Turkey. With a value exceeding Turkish Lira (TL) 10 billion, Konya also ranks first in total agricultural production in Turkey (MEVKA, 2016; TURKSTAT, 2016).

The aims of the study were to analyze poverty with nonmonetary methods by using wealth index calculated via Principle Component Analyses (PCA), examine poverty with the dimension of welfare and note the differences by comparing it with the monetary approach in the province of Konya which is one of the most important agricultural production areas of Turkey. The main question is how the non-monetary approach differs from the income based approach and the relation between welfare and wealth in rural areas of the Konya Province in Turkey. This is also one of the important study showing the results on multidimensional poverty for agricultural community in rural areas of Turkey.

\section{MATERIALS AND METHODS}

Study area and data collection: The data in the study was collected by using the questionnaires interviews with 713 head of agricultural farms registered to Farmers Registration System (CKS) and/or Veterinary Information Registry System (TURKVET) in 170 villages in a total of 31 districts of Konya province including the central districts in 2010. The "Purposeful Sampling" method, which is a technique widely used in qualitative research for the identification and selection of information-rich cases for the most effective use of limited resources (Patton, 2002), and involves identifying and selecting individuals or groups of individuals that are especially knowledgeable about or experienced with a phenomenon of interest (Cresswell and Plano Clark, 2011), was used for determining the settlements in Konya province for this research. First, agricultural areas were identified together with county agricultural offices and other agricultural organizations, mainly the Konya Provincial Directorate of Food, Agriculture and Livestock operating in the research field, taking into consideration the agricultural, geographical and climatic characteristics of Konya province.
A total of 170 settlements of Konya Province were selected by taking into account the different agricultural regions in the province (agricultural basins), the existing agricultural production systems in the province (land to be rainfed and irrigated), patterns of different products within the agricultural production system of the province and different altitude measurements of the province. For determining settlement areas, locations which were considered to be rural areas under the VIII. National Five Years Development Plan (2001-2005) of Ministry of Development and having a population below 20,000 (MoD, 2000).

The agricultural basins of the settlement areas were determined according to the tables published in the Official Gazette according to the Decision of the Council of Ministers numbered 2009/15173 regarding "Determination of Agricultural Basins in Turkey" (O.G., 2009). According to this table, there are three pieces of agricultural basins in Konya Province. These are:

- Central Anatolian Agricultural Basin (Altinekin, Cihanbeyli, Celtik, Cumra, Emirgazi, Eregli, Guneysınır, Halkapınar, Kadınhanı, Karapınar, Karatay, Kulu, Sarayonu, yunak)

- Inner Aegean Agricultural Basin (Aksehir, Doganhisar, Ilgin, Tuzlukcu)

- Lakes Agricultural Basin (Ahirli, Akoren, Beysehir, Bozkir, Derbent, Derebucak, Hadim, Huyuk, Meram, Seydisehir, Selcuklu, Taskent, Yalıhuyuk)

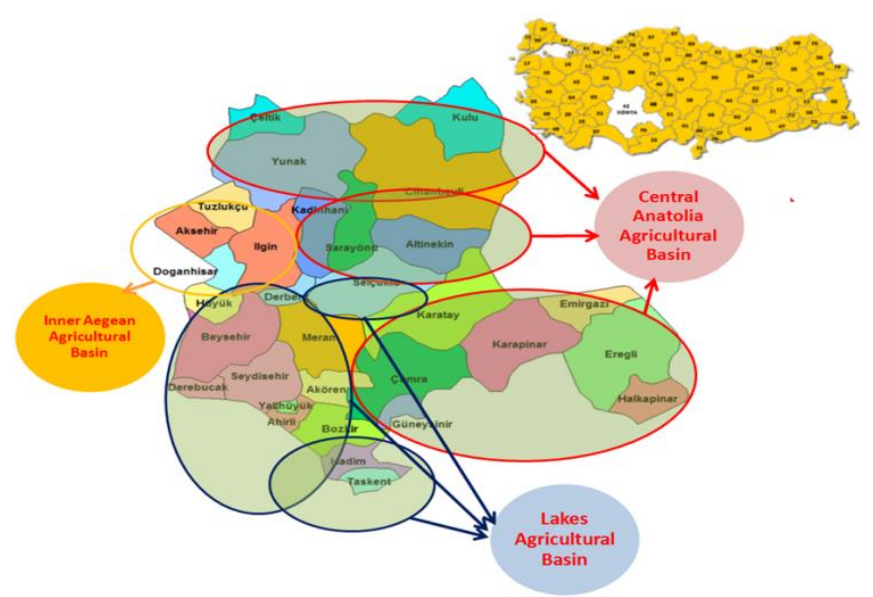

Figure 1. Turkey/Konya map and agricultural basins.

The CKS and TURKVET databases have been used to determine agricultural farms for the project. The main scope of the study consists of the agricultural farms registered in CKS and TURKVET for the year of 2008. In the settlements selected in 2008, there were 118,411 agricultural farms in total. The population showed a heterogenic structure (Coefficient of Variation: 98\%), because of that, "Stratified Sampling Method" was used. Using this Method, it was determined that the number of agricultural farms that would 
be included in the project were 713 farms in 170 settlements in Konya Province.

Data analysis: Chi-Square Analysis was used to determine whether there is a statistically significant relationship between the variables in the cross-tables (Bayazit and Oguz, 1998). When this limit is exceeded, the reliability of the results obtained from chi-square analysis shall be questioned. Therefore, where Chi-Square Analysis is not valid, "Likelihood Ratio" value was used. The data was tested according to 90, 95 and 99\% of the reliability limit. "T Test", compares the average of the two independent variables, was used for independent variables. Levene's Test was used to assess the equality of variances for a variable calculated for two or more groups (Ergun, 1995; Buyukozturk, 2012). Also, in this study, the continuous variables (for more than 2 variables) were analyzed by using variance analyses (F Test) which is a parametrical test. If the parametrical tests are not suitable, then non-parametrical tests such as Kruskal-Wallis, Median Test, Mann Whitney U Test, and Kolmogorov Simirnow Test were utilized (Duzguneş et al., 1983).

For the determination of the poverty level of agricultural enterprises, the approaches of relative poverty were identified in the areas where the study was carried out. In the study, for calculation of the poverty line, the income method was taken into consideration (Rendtel et al., 1998; Ghazouani and Goaied, 2001; Corsi and Orsini, 2002; Odhiambo and Manda, 2003; Ozcan and Ozcan, 2003; Adams, 2004). In this study, for determining the relative poverty rate, $50 \%$ of the median value of the equivalent amount of per capita of total enterprise income was taken into consideration.

The term considered in the poverty line is "equivalent person (EP)". When determining the number of equivalent person, the "equivalence scale", developed by FAO, was used. The scale used in the conversion of equivalent individual is presented in Table 1.

Table 1. The FAO scale based the minimum calorie requirements calculation of demographic groups.

\begin{tabular}{lc}
\hline Demographic Groups & $\boldsymbol{\alpha}$ coefficient \\
\hline Children $(5$ age $<)$ & 0.64 \\
Children $(5-17$ age $)$ & 1.00 \\
Men $(18-39$ age $)$ & 1.00 \\
Women $(18-39$ age) & 0.84 \\
Men $(40$ age + ) & 0.88 \\
Women $(40$ age +$)$ & 0.76 \\
\hline
\end{tabular}

Source: TURKSTAT (2008).

Wealth index, based on the status of household assets, was calculated using the factor analysis and was used for ranking households in the sample. In the wealth ranking, variables important in distinguishing households from each other were identified by using the Principal Components Analysis (PCA) and wealth quartiles were used to explore patterns of household income distribution. In the factor analysis, sets of variables are grouped by their correlations, thus each group represents a single underlying construct or factor, though it is subjective and factors must be interpreted relying on previous knowledge and intuition about underlying relationships. Notably, 22 variables were used to represent household wellbeing (Table 2). The estimation of relative wealth using PCA is based on the first principal component. Formally, the wealth index for each household is the linear combination

$$
\mathrm{y}_{\mathrm{i}}=\propto_{1}\left(\frac{\mathrm{x}_{1}-\overline{\mathrm{x}}_{1}}{\mathrm{~s}_{1}}\right)+\propto_{1}\left(\frac{\mathrm{x}_{2}-\overline{\mathrm{x}}_{2}}{\mathrm{~s}_{2}}\right)+\cdots+\propto_{\mathrm{k}}\left(\frac{\mathrm{x}_{\mathrm{k}}-\overline{\mathrm{x}}_{\mathrm{k}}}{\mathrm{s}_{\mathrm{k}}}\right)
$$

In the equation $1, \bar{x}_{k}$ and $s_{k}$ are the mean and standard deviation of asset $x_{k}$, and $\alpha$ represents the weight for each variable $x_{k}$ for the first principal component. By definition the first principal component variable across households or individuals has a mean of zero and a variance of $\lambda$, which corresponds to the largest eigenvalue of the correlation matrix of " $x$ ". The first principal component " $y$ " yields a wealth index that assigns a larger weight to assets that vary the most across households so that an asset found in all households is given a weight of zero (McKenzie, 2005). The first principal component or wealth index can take positive as well as negative values.

\section{RESULTS AND DISCUSSION}

Relative poverty in the research area: To determine the relative poverty line in the research area, $50 \%$ of the average value of equivalent quantity per capita of total farms income obtained by the calculation of datum gotten via a survey from agricultural farms has been taken into consideration. The general relative poverty line, according to purchasing power parity (1\$: TL 0.99), was calculated as $\$ 2,703$ per EP. It means that the poverty line per EP per day was $\$ 7.41$ in the research area. The ratio of agricultural holdings under the poverty line (head count ratio) was $30.15 \%$. The number of people in the poor agricultural holdings was determined to average 5.38 (4.81 EP), this value in the non-poor agricultural holdings were counted as 5.03 (4.45 EP). The study found that poverty changes according to agricultural basins. In particular, more than $40 \%$ of the agricultural holdings in the Inner Aegean (41.59\%) and the Lakes Agricultural Basins $(40.89 \%)$ were under the poverty line and in the Central Anatolian Agricultural Basin it was $21.41 \%$.

Geographical dimension of poverty: Since poor individuals have a tendency to concentrate in certain areas, poverty is not a homogenous concept in spatial area (Henninger and Snel, 2002). The differences in poverty intensity are showed from a spatial point of view and these become significant by using individual and household characteristics (Bigman and Fofack, 2000). In the studies relevant to poverty, the social variables of poverty are mostly emphasized and spatial characteristics are not adequately taken into consideration (Milbourne, 2004). However, the life standards of individuals become 
Table 2. Sets of variables used in factor analysis for wealth index.

\begin{tabular}{|c|c|c|c|}
\hline \multicolumn{4}{|c|}{ Variables } \\
\hline 1 & Production System & 9 & Phone Line \\
\hline & Rainfed & & Owner \\
\hline & Irrigated & & Non Owner \\
\hline \multirow[t]{4}{*}{2} & Agricultural Basins & 10 & Internet Line \\
\hline & Central Anatolian Agricultural Basin & & Owner \\
\hline & Inner Aegean Agricultural Basin & & Non Owner \\
\hline & Lakes Agricultural Basin & 11 & Dishwasher \\
\hline \multirow[t]{5}{*}{3} & Farm Size & & Owner \\
\hline & 1. Stratify (0-4 ha) & & Non Owner \\
\hline & 2. Stratify (4.01-6 ha) & 12 & Washing Machine \\
\hline & 3. Stratify $(6.01-10$ ha) & & Owner \\
\hline & 4. Stratify $(10.01-+$ ha $)$ & & Non Owner \\
\hline \multirow[t]{3}{*}{4} & Status in Society & 13 & Air-conditioner \\
\hline & Leader/Pioneer & & Owner \\
\hline & Others & & Non Owner \\
\hline \multirow[t]{3}{*}{5} & Benefit from State Aid & 14 & Transportation Vehicle \\
\hline & Owner & & Owner \\
\hline & Non Owner & & Non Owner \\
\hline \multirow[t]{3}{*}{6} & Indoors Toilet & 15 & Equipment Capital (\$) \\
\hline & Owner & 16 & The House Age (Year) \\
\hline & Non Owner & 17 & Elevation $(\mathrm{m})$ \\
\hline \multirow[t]{3}{*}{7} & Continuous Hot Water & 18 & The Number of Equivalent Person in the HH (EP) \\
\hline & Owner & 19 & Total Production Area (Ha) \\
\hline & Non Owner & 20 & The Share of Irrigated Land in Total Land (\%) \\
\hline \multirow[t]{3}{*}{8} & Covered Garage & 21 & Total Animal Unit \\
\hline & Owner & 22 & The Number of Flat \\
\hline & Non Owner & & \\
\hline
\end{tabular}

different according to the geographical environment where they live. In many countries, the regional differences in the standard of living are obvious. These differences also bring inequality with them, and cause "poverty pockets" in both poor and rich countries (Bigman and Fofack, 2000). Spatial differences present in the poverty distribution raise questions as to why those poor areas appear, and to what degree geography is a determinant (Ravallion and Wodon, 1999). Therefore, the relationship between the geographical structure of the study area and the wealth index formed agricultural enterprises were examined.

Farmers in irrigated agricultural system and flatter lands, indicates that agricultural enterprises are in better condition in terms of wealth (Table 3). In terms of the socioeconomic development index of districts, developed by the Ministry of Development in 2004, the Lakes Agricultural Basin Region includes the mountainous and the most underdeveloped settlement places of Konya (MoD, 2004). In the study, the results suggested that poverty is more prevalent in the province of Konya, in which rural high and rainfed agricultural systems prevail. Similarly, having access to rich village natural resources is an element affecting the welfare factor in agricultural enterprises. In many previous studies, it has been determined that poverty isolation, in a geographical sense, is seen in areas in which resources are insufficient and tough climatic conditions exist (Haughton and Khandker, 2009; Bijava et al., 2015). It is accepted that poverty rates are higher in areas where inadequate education and health conditions are prevalent as well as areas where there are security problems, restriction of political freedoms, and a lack of confidence by the people. With the exception of low income level, poverty is accepted as the interaction of the inadequacies seen in all socioeconomic functions of a geographical environment (Akgiş and Akbulak, 2015). According to the geographical model of Ravallion, in these areas, the mobility of individuals is limited and poverty is related to spatial elements, because local factors such as climatic conditions, soil properties, infrastructure, and social services affect marginal conversion of investments (Henninger, 1998).

Income dimension of poverty: In order to measure the welfare of the enterprises interviewed in the study area, a wealth index was formed from a set of variables consisting of 22 indicators. Here, relationships between income, welfare, and poverty in agricultural area was established. As a result of the poverty analysis according to income, it was found that $30.15 \%$ of respondents remained below the poverty line (2,479 Turkish Lira/Equivalent Person). Notably, many studies in Turkey have shown that the methods for measuring poverty according to income have been inadequate for measuring the intensity of poverty. Ultimately, it was discovered that although the percentage of poor people is lower, their poverty is deeper and their conditions are worse than income based estimations in Turkey. Therefore, the 
Kan, Oguz, Kan, Ergun \& Demiroz

Table 3. Descriptive statistics of variable applied factor analysis (geographical dimension of poverty).

\begin{tabular}{|c|c|c|c|c|c|c|c|c|c|c|c|c|c|c|}
\hline & \multicolumn{12}{|c|}{ Wealth Quartiles } & \multirow{3}{*}{$\begin{array}{c}\text { Chi- } \\
\text { Square/F } \\
\text { Value }\end{array}$} \\
\hline & & \multicolumn{3}{|c|}{$75 \%-100 \%$} & \multicolumn{3}{|c|}{$50 \%-75 \%$} & \multicolumn{3}{|c|}{$25 \%-50 \%$} & \multicolumn{3}{|c|}{$0 \%-25 \%$} & \\
\hline & & $\overline{\text { Count }}$ & $\%$ & Mean & Count & $\%$ & Mean & Count & $\%$ & Mean & Count & $\%$ & Mean & \\
\hline Elevation $(\mathrm{m})$ & & & & 1066.24 & & & 1102.36 & & & 1149.93 & & & 1256.38 & \\
\hline Production & Irrigated & 101 & 61.21 & & 50 & 30.30 & & 34 & 20.61 & & 18 & 10.98 & & $109.90 * * *$ \\
\hline System & Rainfed & 64 & 38.79 & & 115 & 69.70 & & 131 & 79.39 & & 146 & 89.02 & & \\
\hline \multirow{6}{*}{ 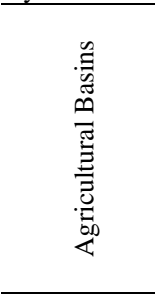 } & Central Anatolia & 127 & 76.97 & & 111 & 67.27 & & 83 & 50.30 & & 41 & 25.00 & & $154.56^{* * * *}$ \\
\hline & $\begin{array}{l}\text { Agricultural } \\
\text { Basin }\end{array}$ & & & & & & & & & & & & & \\
\hline & Inner Aegean & 25 & 15.15 & & 29 & 17.58 & & 31 & 18.79 & & 18 & 10.98 & & \\
\hline & $\begin{array}{l}\text { Agricultural } \\
\text { Basin }\end{array}$ & & & & & & & & & & & & & \\
\hline & Lakes & 13 & 7.88 & & 25 & 15.15 & & 51 & 30.91 & & 105 & 64.02 & & \\
\hline & $\begin{array}{l}\text { Agricultural } \\
\text { Basin }\end{array}$ & & & & & & & & & & & & & \\
\hline \multirow{2}{*}{$\begin{array}{l}\text { Geographical } \\
\text { Location }\end{array}$} & Lowland & 143 & 86.67 & & 127 & 76.97 & & 121 & 73.33 & & 69 & 42.07 & & 87.08 **** \\
\hline & Highland & 22 & 13.33 & & 38 & 23.03 & & 44 & 26.67 & & 95 & 57.93 & & \\
\hline Village & Resource-Rich & 63 & 38.18 & & 60 & 36.36 & & 61 & 38.61 & & 50 & 32.47 & & $11.34 *$ \\
\hline \multirow[t]{3}{*}{ Definition } & Resource- & 67 & 40.61 & & 64 & 38.79 & & 52 & 32.91 & & 77 & 50.00 & & \\
\hline & Norma & & & & & & & & & & & & & \\
\hline & Resource-Poor & 35 & 21.21 & & 41 & 24.85 & & 45 & 28.48 & & 27 & 17.53 & & \\
\hline
\end{tabular}

*Statistically significant at $90 \%$ confidence level; $* *$ Statistically significant at $95 \%$ confidence level; $* * *$ Statistically significant at $99 \%$ confidence level.

Table 4. Descriptive statistics of variable applied factor analysis (income dimension of poverty).

\begin{tabular}{|c|c|c|c|c|c|}
\hline & \multicolumn{4}{|c|}{ Wealth Quartiles } & \multirow{2}{*}{$\begin{array}{c}\text { F Value/K-W } \\
\text { Value }\end{array}$} \\
\hline & $75 \%-100 \%$ & $50 \%-75 \%$ & $25 \%-50 \%$ & $0 \%-25 \%$ & \\
\hline Total Land Size $(\mathrm{Ha})$ & 9.90 & 12.64 & 15.33 & 18.19 & $8.56 * * *$ \\
\hline Irrigated Land Size (Ha) & 7.03 & 6.11 & 5.75 & 3.81 & $2.52 * *$ \\
\hline The Share of Irrigated Land in Total Land (\%) & 71.02 & 48.31 & 37.49 & 20.97 & \\
\hline Cattle Number & 2.88 & 3.53 & 4.16 & 7.50 & $6.00 * * *$ \\
\hline Number of Sheep and Goats & 9.76 & 16.55 & 15.88 & 47.15 & $4.81 * * *$ \\
\hline Total Animal Unit & 3.10 & 4.08 & 4.66 & 9.95 & $11.13 * * *$ \\
\hline Total Gross Value (\$) & 25,496 & 26,941 & 28,208 & 41,141 & $3.91 * * *$ \\
\hline Crop Gross Value(\$) & 20,197 & 18,631 & 20,401 & 23,882 & 0.55 \\
\hline Animal Gross Value (\$) & 5,299 & 8,310 & 7,807 & 17,258 & $8.47 * * *$ \\
\hline Gross Margin (\$) & 14,203 & 15,480 & 15,128 & 19,758 & 1.35 \\
\hline Net Margin (\$) & 3,674 & 4,511 & 2,867 & 4,793 & 0.25 \\
\hline Total Agricultural Income (\$) & 11,887 & 12,546 & 12,099 & 16,848 & 1.46 \\
\hline Total Agricultural Supports (\$) & 2,087 & 2,471 & 2,888 & 3,385 & $5.31 * * *$ \\
\hline Total Non-Agricultural Income (\$) & 10,520 & 9,349 & 8,310 & 9,553 & $20.91 * * *$ \\
\hline Total Income Per Equivalent Person $(\$)^{1}$ & $\begin{array}{c}6,269 \\
(4,067)\end{array}$ & $\begin{array}{c}5,262 \\
(3,471)\end{array}$ & $\begin{array}{c}4,796 \\
(3,157)\end{array}$ & $\begin{array}{c}5,263 \\
(2,222)\end{array}$ & $14.87 * * *$ \\
\hline
\end{tabular}

${ }^{1}$ The values in parenthesis show the median values, 1\$:1.50TL; *Statistically significant at $90 \%$ confidence level; **Statistically significant at $95 \%$ confidence level; ***Statistically significant at $99 \%$ confidence level.

multidimensional approach provides more information than income based poverty and thus enlightens Turkey's lower human development ranking.

Results shows that from the total $16.36 \%$ of the enterprises, whose wealth level is in the highest slice (75-100\%), their poverty increases as wealth level falls. It was identified that this rate was statistically significant $\left(\chi^{2}: 30.38, \mathrm{p}: 0.00\right)$. Also, from a monetary stance, along with the wealth level, equivalent per capita income also changes in the same way. Due to the fact that distribution is not normal, as a result of Kruskal Wallis $(\mathrm{K}-\mathrm{W})$ test, different equivalent per capita income according to wealth level was found statistically significant (K-W: 14.87, p:0.00). Income and wealth vary and depend on each other in agricultural rural areas. It is also important to note that the determinant element in income is non-agricultural income and not the agricultural income. Further, agricultural income is not statistically significant (F Value: 0.29 , p: 0.83), in the area where non-agricultural income is high, however it was identified that wealth is higher (K-W: 20.91, p: 0.00) (Table 4).

Another important point related to income is agricultural income. In the study, the group in which wealth is low, the 
number of sheep, goat and cattle are higher $\left(\mathrm{F}_{\text {smallrum: }}: 4.81\right.$, $\mathrm{p}: 0.00 ; \mathrm{F}_{\text {bigrum: }}: 0.00$, p:0.00). In the group in which wealth is high, albeit total amount of land is less in size, the amount of irrigated land is more compared to the other groups

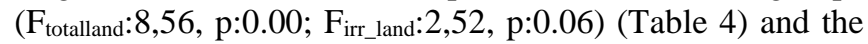
relationship found between geographical structure and income/wealth is again seen here. Even though agricultural enterprises mostly engage in breeding, wealth is low, the wealth of the agricultural enterprises in flat and irrigated areas was found to be higher. In rain-fed agricultural areas, where land is more, a lower wealth level was seen. In the present study, the results were similar.

Social dimension of poverty: Poverty is a multidimensional concept. The welfare and happiness of people are the main aims of development economics. This aim is often said to struggle with poverty in much of the literature that can be found today. Further, recent literature has described the welfare of people in a much broader perspective. While definitions and measurements of human welfare are made, besides monetary criteria like income, the broader definitions are created by using non-monetary indicators that are taking place such as social elements. Therefore, welfare (or poverty) that is multidimensional cannot be accounted for using only monetary indicators. Further, there is also a need for indicators which cannot be expressed monetarily. If income or consumption by humans are high, in a non-monetary dimension, he/she can also improve his/her circumstance in the dimensions. However, he/she can improve his/her conditions in the dimensions which cannot be expressed monetarily but if there is no market for the dimension, which cannot be monetarily expressed despite his/her high income, the individual cannot increase his/her welfare. Therefore, income is not solely accepted as an indicator of human welfare. In addition to income, indicators such as life expectancy, nutritional level, literacy rate, accessibility to public goods, which cannot be monetarily stated, have to be used (Chakravarty, 2005).

Notably, a person who is above the poverty line, calculated by using income/ consumption data, may not be literate and healthy. While he/she has income/consumption over the poverty line, if he/she is devoid of clean water, essential health services or is illiterate, he/she is not deemed as poor. A multidimensional approach, in which non- monetary indicators are spaciously used, enables human development/poverty to be better understood, and to be able to be struggled against poverty. While the improvements in the selected dimensions show human development, among these dimensions, the rates of deprivation show the levels of human poverty (Anand and Sen, 1997).

In many countries, poverty is more common of a problem in rural areas and deficiencies in personal consumption, education, health, clean water, housing, access to transport and communication services are all factored into rural poverty. Therefore, inadequate levels of the aforementioned resources increases rural poverty and fosters migration to urban areas. As a consequence of it, underdevelopment in rural areas hinders the sustainability of economic growth in urban areas. Increasing poverty as a result of the neglected rural areas and rural-urban migration is also the main reason of urban poverty (Kocatepe, 2011)

In the study, the social development index developed by the Mevlana Development Agency in 2011 for TR-52 Region (Konya and Karaman Provinces) on the level of their districts were used (MEVKA, 2011). This index covers 17 total variables including demography, education, and health indicators. This index was matched with the survey area and investigated the relation between the social development index and the poverty and wealth index developed in the research. Figure 2 shows the relation with the social development index and the variables (agricultural systems and geographical locations) are statistically significant (T value $_{\text {ag.sys }}=3.30, \mathrm{p}: 0.00$ and $\mathrm{T}$ value geo. loc $\left.=2.51, \mathrm{p}: 0.01\right)$ which means that the findings support the results obtained using the poverty analysis and the wealth index scores.

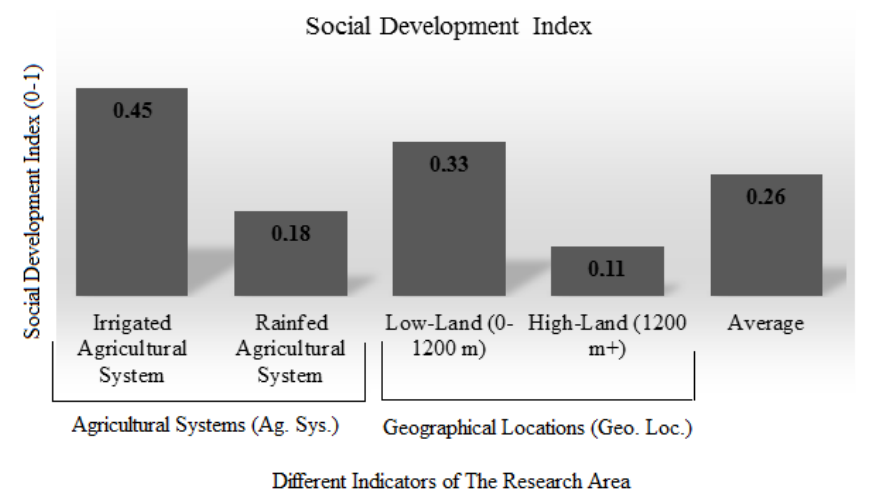

Figure 2. Social development index by the agricultural systems and geographical locations.

In the present study, the other indicators were age of house, that it has garden, that it has warm water, and some electrical devices in house (TV, refrigerator, air conditioner, washing machine, dish washer, phone line, internet line, computer and satellite of the houses they live (Table 5). In addition, other factors such as membership by the head of household in a cooperative, status in society, government assistance, and the number of equivalent person in house were examined.

As a result of the study, the case of having all elements except refrigerator possession, television, and satellite antenna shows wealth increase. Especially, internet access, computer, washing machine, dish washer and transportation vehicles are important variables showing remarkable differences among these indicators. In a study in 2008, Córdova computed the wealth index in the Latin American Public Opinion Project (LAPOP) surveys for both urban and rural areas of Peru and Costa Rica. The researcher, due to the fact that TV ownership is very prevalent in urban area of both countries, suggests that 
Kan, Oguz, Kan, Ergun \& Demiroz

Table 5. Descriptive statistics of variable applied factor analysis (social dimension of poverty).

\begin{tabular}{|c|c|c|c|c|c|c|c|c|c|c|c|c|c|c|}
\hline & \multicolumn{12}{|c|}{ Wealth Quartiles } & \multirow{3}{*}{$\begin{array}{c}\text { Chi- } \\
\text { Square/ F } \\
\text { Value }\end{array}$} \\
\hline & & \multicolumn{3}{|c|}{$75 \%-100 \%$} & \multicolumn{3}{|c|}{$50 \%-75 \%$} & \multicolumn{3}{|c|}{$25 \%-50 \%$} & \multicolumn{3}{|c|}{$0 \%-25 \%$} & \\
\hline & & Count & $\%$ & Mean & Count & $\%$ & Mean & Count & $\%$ & Mean & Count & $\%$ & Mean & \\
\hline \multicolumn{2}{|c|}{$\begin{array}{l}\text { Total Equivalent Person in the } \\
\text { Household }\end{array}$} & & & 4.08 & & & 4.22 & & & 4.60 & & & 5.37 & \\
\hline $\begin{array}{l}\text { Status in } \\
\text { Society }\end{array}$ & $\begin{array}{l}\text { Leader/Pioneer } \\
\text { Others }\end{array}$ & $\begin{array}{c}30 \\
135\end{array}$ & $\begin{array}{l}18.18 \\
81.82\end{array}$ & & $\begin{array}{c}41 \\
124\end{array}$ & $\begin{array}{l}24.85 \\
75.15\end{array}$ & & $\begin{array}{c}46 \\
119\end{array}$ & $\begin{array}{l}27.88 \\
72.12\end{array}$ & & $\begin{array}{c}44 \\
120\end{array}$ & $\begin{array}{l}26.83 \\
73.17\end{array}$ & & 5.08 \\
\hline Cooperative & Yes & 153 & 93.29 & & 153 & 95.03 & & 148 & 90.24 & & 160 & 97.56 & & $8.27 * *$ \\
\hline Membership & No & 11 & 6.71 & & 8 & 4.97 & & 16 & 9.76 & & 4 & 2.44 & & \\
\hline \multicolumn{2}{|c|}{ House Age (Year) } & & & 23.01 & & & 31.51 & & & 36.97 & & & 48.66 & \\
\hline $\begin{array}{l}\text { The Source of } \\
\text { Heating }\end{array}$ & $\begin{array}{l}\text { Through Own } \\
\text { Mean }\end{array}$ & 157 & 96.91 & & 158 & 98.75 & & 159 & 98.15 & & 147 & 89.63 & & $21.84 * * *$ \\
\hline Requirements & State Aid & 5 & 3.09 & & 2 & 1.25 & & 3 & 1.85 & & 17 & 10.37 & & \\
\hline Benefit from & Never Benefit & 157 & 95.15 & & 162 & 98.18 & & 160 & 96.97 & & 140 & 85.37 & & $29.44 * * *$ \\
\hline State Aid & I benefited & 8 & 4.85 & & 3 & 1.82 & & 5 & 3.03 & & 24 & 14.63 & & \\
\hline \multirow[t]{2}{*}{ Indoors Toilet } & Owner & 141 & 85.45 & & 120 & 72.73 & & 103 & 62.42 & & 110 & 67.07 & & $24.30 * * *$ \\
\hline & Non Owner & 24 & 14.55 & & 45 & 27.27 & & 62 & 37.58 & & 54 & 32.93 & & \\
\hline Continuous & Owner & 145 & 87.88 & & 129 & 78.18 & & 107 & 64.85 & & 84 & 51.22 & & $60.56 * * *$ \\
\hline Hot Water & Non Owner & 20 & 12.12 & & 36 & 21.82 & & 58 & 35.15 & & 80 & 48.78 & & \\
\hline Covered & Owner & 78 & 47.27 & & 56 & 33.94 & & 62 & 37.58 & & 54 & 32.93 & & $8.99 * *$ \\
\hline Garage & Non Owner & 87 & 52.73 & & 109 & 66.06 & & 103 & 62.42 & & 110 & 67.07 & & \\
\hline \multirow[t]{2}{*}{ Garden } & Owner & 114 & 69.09 & & 108 & 65.45 & & 99 & 60.00 & & 86 & 52.44 & & $10.96^{* *}$ \\
\hline & Non Owner & 51 & 30.91 & & 57 & 34.55 & & 66 & 40.00 & & 78 & 47.56 & & \\
\hline \multirow[t]{2}{*}{ Phone Line } & Owner & 143 & 86.67 & & 144 & 87.27 & & 118 & 71.52 & & 96 & 58.54 & & $51.06^{* * * *}$ \\
\hline & Non Owner & 22 & 13.33 & & 21 & 12.73 & & 47 & 28.48 & & 68 & 41.46 & & \\
\hline \multirow[t]{2}{*}{ Computer } & Owner & 74 & 44.85 & & 33 & 20.00 & & 23 & 13.94 & & 18 & 11.11 & & $66.78 * * *$ \\
\hline & Non Owner & 91 & 55.15 & & 132 & 80.00 & & 142 & 86.06 & & 144 & 88.89 & & \\
\hline
\end{tabular}

Table 5 (Cont.). Descriptive statistics of variable applied factor analysis (social dimension of poverty).

\begin{tabular}{|c|c|c|c|c|c|c|c|c|c|c|}
\hline & \multicolumn{8}{|c|}{ Wealth Quartiles } & \multirow{3}{*}{$\begin{array}{c}\text { Chi- } \\
\text { Square/ } \\
\text { F Value }\end{array}$} \\
\hline & & \multicolumn{2}{|c|}{$75 \%-100 \%$} & \multicolumn{2}{|c|}{$50 \%-75 \%$} & \multicolumn{2}{|c|}{$25 \%-50 \%$} & \multicolumn{2}{|c|}{$0 \%-25 \%$} & \\
\hline & & Count & $\%$ & Count & $\%$ & Count & $\%$ & Count & $\%$ & \\
\hline \multirow[t]{2}{*}{ Internet Line } & Owner & 65 & 39.39 & 24 & 14.55 & 18 & 10.91 & 12 & 7.32 & $70.62^{* * * *}$ \\
\hline & Non Owner & 100 & 60.61 & 141 & 85.45 & 147 & 89.09 & 152 & 92.68 & \\
\hline \multirow[t]{2}{*}{ Television } & Owner & 164 & 99.39 & 165 & 100 & 162 & 98.18 & 161 & 98.17 & 3.91 \\
\hline & Non Owner & 1 & 0.61 & 0 & 0 & 3 & 1.82 & 3 & 1.83 & \\
\hline \multirow[t]{2}{*}{ Refrigerator } & Owner & 164 & 99.39 & 164 & 99.39 & 163 & 98.79 & 162 & 98.78 & 0.68 \\
\hline & Non Owner & 1 & 0.61 & 1 & 0.61 & 2 & 1.21 & 2 & 1.22 & \\
\hline \multirow[t]{2}{*}{ Dish Machine } & Owner & 61 & 36.97 & 24 & 14.55 & 11 & 6.67 & 13 & 7.93 & $70.83^{* * * *}$ \\
\hline & Non Owner & 104 & 63.03 & 141 & 85.45 & 154 & 93.33 & 151 & 92.07 & \\
\hline Washing & Owner & 163 & 98.79 & 160 & 96.97 & 156 & 94.55 & 141 & 85.98 & $28.45^{* * * *}$ \\
\hline Machine & Non Owner & 2 & 1.21 & 5 & 3.03 & 9 & 5.45 & 23 & 14.02 & \\
\hline \multirow{2}{*}{ Air-Conditioner } & Owner & 14 & 8.48 & 2 & 1.21 & 1 & 0.61 & 0 & 0 & $31.02^{* * * *}$ \\
\hline & Non Owner & 151 & 91.52 & 163 & 98.79 & 164 & 99.39 & 164 & 100 & \\
\hline \multirow{2}{*}{ Satellite } & Owner & 111 & 67.27 & 109 & 66.06 & 108 & 65.45 & 107 & 65.24 & 0.18 \\
\hline & Non Owner & 54 & 32.73 & 56 & 33.94 & 57 & 34.55 & 57 & 34.76 & \\
\hline \multirow{2}{*}{$\begin{array}{l}\text { Transportation } \\
\text { Vehicle }\end{array}$} & Owner & 120 & 72.73 & 105 & 63.64 & 82 & 49.7 & 58 & 35.37 & $53.39 * * *$ \\
\hline & Non Owner & 45 & 27.27 & 60 & 36.36 & 83 & 50.3 & 106 & 64.63 & \\
\hline \multirow{3}{*}{$\begin{array}{l}\text { Relative } \\
\text { Poverty }\end{array}$} & Poor & 19 & 11.52 & 26 & 15.76 & 40 & 24.24 & 35 & 21.34 & $11.246^{*}$ \\
\hline & Normal & 126 & 76.36 & 123 & 74.55 & 111 & 67.27 & 113 & 68.9 & \\
\hline & Rich & 20 & 12.12 & 16 & 9.7 & 14 & 8.48 & 16 & 9.76 & \\
\hline \multirow[t]{2}{*}{ Poverty } & Poor & 27 & 16.36 & 45 & 27.27 & 57 & 34.55 & 71 & 43.29 & $30.38^{* * * *}$ \\
\hline & Non-Poor & 138 & 83.64 & 120 & 72.73 & 108 & 65.45 & 93 & 56.71 & \\
\hline \multirow[t]{6}{*}{ Human Nature } & Hardworking & 1 & 0.61 & 4 & 2.42 & 2 & 1.27 & 0 & 0 & $36.72 * * *$ \\
\hline & Helpful & 70 & 42.42 & 68 & 41.21 & 58 & 36.71 & 51 & 33.12 & \\
\hline & Envy & 10 & 6.06 & 14 & 8.48 & 7 & 4.43 & 5 & 3.25 & \\
\hline & Immiscible & 34 & 20.61 & 42 & 25.45 & 49 & 31.01 & 69 & 44.81 & \\
\hline & $\begin{array}{l}\text { Hardworking } \\
\text { and Helpful }\end{array}$ & 37 & 22.42 & 33 & 20 & 34 & 21.52 & 23 & 14.94 & \\
\hline & $\begin{array}{l}\text { Hardworking } \\
\text { and Immiscible }\end{array}$ & 13 & 7.88 & 4 & 2.42 & 8 & 5.06 & 6 & 3.9 & \\
\hline
\end{tabular}

*Statistically significant at $90 \%$ confidence level; **Statistically significant at $95 \%$ confidence level; ***Statistically significant at 99 $\%$ confidence level.

it makes very little contribution to score value formed for welfare index. Despite this, it was suggested that on the contrary, ownership of a microwave oven, washing machine, and computer was an important distinction. Further, it was reported that that families who own vehicles is a positive indicator of welfare.

In Turkey, according to statistics published by TURKSTAT on poverty pertaining to material deprivation, $29.4 \%$ of the population suffer from material deprivation. TURKSTAT 
considered the following elements in calculating material deprivation, mortgage arrearages or late rent payment utility bills or other loan payments, etc., ability to take one annual holiday away from home, capacity to afford a meal with meat such as chicken or fish, every second day, ability to face unexpected financial expenses, owning a telephone (including mobile phone), a color TV, a washing machine, a car and the ability to adequately heat a home (TURKSTAT, 2015). When TURKSTAT statistics are compared with the results obtained in the present study, there was an increase in material deprivation in rural agricultural areas.

Conclusion: Most of the calculations made on poverty, using the income and consumption focused monetary approach, limits us from acquiring information about the non-monetary dimensions of poverty. In this study, as using both monetary (income) and non-monetary poverty calculation (wealth index) approaches, we tried to compare the results for rural area of Konya province-Turkey. As a result of this study, some factors showed opposite results in wealth index between the poor and non-poor agricultural holdings enterprises, Further, the study concluded that rather than the land size of enterprise, amount of irrigated land had more importance. Number of animals is also another important indicator. It was concluded that the enterprises that are poor and whose wealth is low had a larger number of animals. The fact that these kind of enterprises are mostly located in the high areas, which is not appropriate for agricultural lands, and it is compatible with the result that poverty is more prevalent in harsher geographical conditions. This is true especially in areas in which the rainfed farming system is predominant. Nonfarming incomes of the holdings found in the highest wealth group (75-100\%) are greater compared to the other groups. It means that poor farm families, growth in income from nonfarm sources is more important than growth in farm income. Using the wealth index has enabled us to acquire more information about the depth of poverty. It is seen that that nonmonetary factors take place in poverty analyses is important in forming the policies toward alleviating poverty. Income did not always turn into welfare, and social factors other than income are effective in this transformation. Multidimensional poverty analysis will help policy makers to design proper targeted policy of poverty alleviation by not only concentrating to income based approach but also asset based approach. Especially in the poverty analyse, welfare and wealth interaction should be put into forward more for agricultural communities in rural areas.

Acknowledgements: The data of the study was compiled from the Project "Poverty Analysis in Agricultural Holding in Rural Area of Konya and Modeling the Appropriate Strategies" supported by the Ministry of Food, Agriculture and Livestock as R\&D Project (TAGEM/09/AR-GE/12) in Turkey.

\section{REFERENCES}

Akgiş, O. and C. Akbulak. 2015. Kırsal yoksullugun cografi açıdan analizi: Yenice ilçesi (Çanakkale) ornegi. Intl. J. Human Sci. 12:547-569.

Ali, I., A. Barrientos and A. Saboor. 2015. Pro-poor growth across different agro-climatic zones of rural Pakistan. Pak. J. Agri. Sci. 52:497-503.

Alkire, S. and M.E. Santos. 2010. Acute multidimensional poverty: a new index for developing countries. Oxford Poverty and Human Development Initiative (OPHI) Working Papers No: 38. Available online with updates at https://www.ophi.org.uk/wp-content/uploads/ophiwp38.pdf

Alkire, S., J.M. Roche, M.E. Santos and S. Seth. 2011. Multidimensional poverty index 2011: brief methodological note. Oxford Poverty and Human Development Initiative (OPHI). Available online with updates at http://www.ophi.org.uk/wpcontent/uploads/MPI_2011_Methodology_Note_4-112011_1500.pdf

Alkire, S. and S. Seth. 2012. Selecting a targeting method to identify BPL households in India. Oxford Poverty and Human Development Initiative (OPHI) Working Papers No 53. Available online with updates at http://www.ophi.org.uk/selecting-a-targeting-methodto-identify-bpl-households-in-india/

Anand, S. and A. Sen. 1997. Concepts of human development and poverty: a multidimensional perspective. In: Poverty and Human Development: Human Development Papers. United Nations Development Programme, New York. pp.1-19.

Atkinson, A. 2003. Multidimensional deprivation: contrasting social welfare and counting approaches. J. Econ. Inequal. 1:51-65.

Bayazit, M. and B. Oguz. 1998. Probability and Statistics for Engineers, ${ }^{\text {st }}$ Ed. Birsen Yayınevi, Istanbul, Turkey.

Berber, M. 2004. İktisadi Buyume ve Kalkınma, 2. Baskı. Derya Kitabevi, Trabzon.

Bigman, D. and H. Fofack. 2000. Geographical targeting for poverty alleviation: methodology and applications. The World Bank, Washington D.C. Available online with updates

at http://documents.worldbank.org/curated/en/6356614687 43807218/Geographical-targeting-for-povertyalleviation-methodology-and-applications

Bijaya G.C.D., S. Cheng, J. Bhandari, L. Xiaojie and Z. Xu. 2015. Multidimensional poverty in Bajhang district of Nepal. Pak. J. Agri. Sci. 52:1131-1137.

Bourguignon, F. and S. Chakravarty. 2003. The measurement of multidimensional poverty. J Econ Inequal. 1:25-49.

Buyukozturk, S. 2012. Sosyal Bilimler Için Veri Analizi El Kitabı. 16. Baskı. PegemA Yayınları, Ankara. 
Cervantes-Godoy, D. and J. Dewbre. 2010. Economic importance of agriculture for poverty reduction. OECD Food, Agriculture and Fisheries Working Papers No. 23. Available online with updates at https://www.oecd.org/tad/44804637.pdf.

Chakravarty, S.R. 2005. An Axiomatic approach to multidimensional poverty measurement via fuzzy sets. In: A. Lemmi and G. Betti (eds.), Fuzzy Set Approach to Multidimensional Poverty Measurement. Indian Statistical Institute, Kolkata, India. pp.49-72.

Chakravarty, S. and C. D'Ambrosio. 2006. The measurement of social exclusion. Rev. Income Wealth 53:377-398.

Cohen, A. 2009. The Multidimensional Poverty Assessment Tool: Design, development and application of a new framework for measuring rural poverty. International Fund for Agricultural Development: Rome. Available online with updates at https://www.ifad.org/documents/10180/d997e46a-f5574f0b-baea-2b03d03f440f

Cordova, A. 2008. Methodological note: measuring relative wealth using household asset indicators. Americas Barometer Insights: 2008 (No.6). pp.1-9. Available online with updates at http://www.vanderbilt.edu/lapop/insights/I0806en_v2.p df

Corsi, M. and K. Orsini. 2002. Measuring poverty in Europe. Development 45:93-101.

Cresswell, J.W. and V.L. Plano Clark. 2011. Designing And Conducting Mixed Method Research, $2^{\text {nd }}$ Ed. Thousand Oaks, CA: Sage.

Deutsch, J. and J. Silber. 2005. Measuring multidimensional poverty: an empirical comparison of various approaches. Rev. Income Wealth 51:145-174.

Duclos, J.Y., D. Sahn and S. Younger. 2006. Robust multidimensional poverty comparisons. The Econ. J. 116:943-968.

Duzguneş, O., T. Kesici and F. Gurbuz. 1983. Statistics Methods I, $1^{\text {st }}$ Ed. University of Ankara Publishing's of Agriculture Faculty, Ankara, Turkey.

Ergun, M. 1995. Bilimsel Araştirmalarda Bilgisayarla İstatistik Uygulamalari SPSS for Windows. 1. Bask1. Ocak Yayınları, Ankara.

Filmer, D. and L.H. Pritchett. 2001. Estimating wealth effect without expenditure data or tears: an application to educational enrollments in states of India. Demography 38:115-32.

Gasparini, L., W.S. Escudero, M. Marchionni and S. Olivieri. 2008. Income, deprivation, and perceptions in Latin America and the Caribbean: New evidence from the Gallup World Poll. Latin American Research Network, Inter-American Development Bank. La Plata, Argentina. Available online with updates at https://publications.iadb.org/bitstream/handle/11319/32
48/Events $\% 20$ management $\% 20$ system $\% 3 a \% 20$ test $\% 20$ document.pdf? sequence $=1$

Ghazouani, S. and M. Goaied. 2001. The determinant of urban and rural poverty in Tunisia. ERF Working Paper Series No:0126. Available online with updates at http://www.academia.edu/19376884/The_Determinants _of_Urban_and_Rural_Poverty_in_Tunisia

Haughton, J. and S. Khandker. 2009. Handbook on Poverty and Inequality. The World Bank, Washington D.C. Available online with updates at http://siteresources.worldbank.org/INTPA/Resources/42 9966-

1259774805724/Poverty_Inequality_Handbook_FrontM atter.pdf

Henninger, N. 1998. Mapping and Geographic Analysis of Human Welfare and Poverty, Review and Assessment. World Resources Institute, Washington, D.C. Available online with updates at http://pdf.wri.org/poverty_mapping_1998.pdf

Henninger, N. and M. Snel. 2002. Where Are the Poor? Experiences with the development and use of poverty maps. World Resources Institute, Washington D.C. Available online with updates at http://pdf.wri.org/wherepoor.pdf

Hicks, N. and P. Streeten. 1979. Indicators of development: the search for a basic needs yardstick. World Development 7:567-580.

IFAD. 2011. Facts and figures, rural poverty report 2011. Available online with updates at https://www.ifad.org/documents/10180/c1bbf5fa-bdc34ea6-9366-d163b95b1180.

IFAD. 2016. Multidimensional poverty assessment tool (MPAT). Available online with updates at https://www.ifad.org/topic/overview/tags/mpat.

Israel, S. and D. Spannagel. 2013. Material deprivation- an analysis of cross-country differences and European convergence. In: Combating Poverty in Europe. European Commission in the $7^{\text {th }}$ Framework Programme. Available online with updates at http://www.coperesearch.eu/wpcontent/uploads/2013/05/Material_Deprivation.pdf.

Kan, A. and C. Oguz. 2012. Women in agriculture and poverty: a case study from highland of Turkey. In. V. Mladjenovic (ed.), Proc. of Poverty Alleviation and Social Protection Conference: March 8-12, 2012. Tomorrow People Organisation, Bangkok, Tayland. pp.1-14.

Karagul, M. and M. Masca. 2005. Sosyal sermaye uzerine bir inceleme. Abant İzzet Baysal Universitesi İktisadi ve İdari Bilimler Fakultesi Ekonomik ve Sosyal Araştırmalar Dergisi 1:37-52.

Kocatepe, H. 2011. Yoksulluk ve kent yoksullugu: Yalova ili ornegi. Yuksek Lisans Tezi, Yalova Univ. Sosyal Bil. Enst., Yalova, Turkiye. 
Labonne, J., D. Biller and R. Chase. 2007. Inequality and relative wealth: Do they matter for trust? Evidence from poor communities in the Philippines. In: Social Development Papers, No:103. The World Bank. Washington, DC. Available online with updates at https://www.commdev.org/userfiles/files/1790_file_J3.p df

Lora, E. 2008. Beyond facts: understanding quality of life. Inter-American Development Bank. Washington, DC. Available online with updates at https://publications.iadb.org/handle/11319/7200?localeattribute $=$ en

Maxwell, S. 1999. The meaning and measurement of poverty. Overseas Development Institute (ODI) Poverty Briefing 3: February 1999. Available online with updates at https://www.odi.org/sites/odi.org.uk/files/odiassets/publications-opinion-files/3095.pdf.

McKenzie, D.J. 2005. Measuring inequality with asset indicators. J. Popul. Econ. 18:229-60.

MEVKA (Mevlana Development Agency). 2011. TR 52 Bolgesi ilçeleri sosyal gelişmişlik endeksi. Bolgesel Araștırma Raporları Serisi, Yayın No. 2, Konya.

MEVKA (Mevlana Development Agency). 2016. Rakamlarla Konya. Available online with updates at http://www.konyadayatirim.gov.tr/.

Milbourne, P. 2004. The local geographies of poverty: a rural case study. Geoforum 35:559-575.

Minujin, A. and J.H. Bang. 2002. Indicadores de inequidad social. Acerca del uso del índice de bienes para la distribución de los hogares. Desarrollo Económico 42:129-146.

MoD (Ministry of Development). 2000. VIII. Beşyillık Kalkinma Plani (2001-2005). Available online with updates at http://www.bilgitoplumu.gov.tr/wpcontent/uploads/2015/01/Sekizinci_Kalkinma_Plani.pdf

MoD. (Ministry of Development). 2004. İlçelerin sosyoekonomik gelişmişlik siralamasi araştirmasi. Available online with updates at http://www.tkhk.gov.tr/Dosyalar/5e32d48195ff4f0a956 8f1d7daf79136.pdf.

Odhiambo, W. and K.D. Manda. 2003. Urban Poverty and Labour Force Participation in Kenya. In. V. Mladjenovic (ed.), Proc. Urban Research Symposium: Dec. 15-17, 2003. The World Bank, Washington, DC. pp.1-19.

O.G. (Official Gazette). 2009. Determination of agricultural basins in Turkey. Available online with updates at http://www.resmigazete.gov.tr/main.aspx?home=http:// www.resmigazete.gov.tr/eskiler/2009/07/20090723.htm \&main=http://www.resmigazete.gov.tr/eskiler/2009/07/ 20090723.htm.

Ozcan, Y.Z. and K.M. Ozcan. 2003. Measuring poverty and inequality in Turkey. Topics in Middle Eastern and North African Economies (electronic journal), Vol. 5.
Available online with updates at http://www.luc.edu/orgs/meea/

Ozturk, S. 2008. Kirsal yoksulluk ve neo-liberal ekonomi politikalari. Uluslararasi Sosyal Arastirmalar Dergisi (The Journal of International Social Research) 1:605634.

Patton, M.Q. 2002. Qualitative Research and Evaluation Methods, $3^{\text {rd }}$ Ed. Thousand Oaks, CA: Sage.

Ravallion, M. and Q. Wodon. 1999. Poor areas or only poor people? J. Regional Sci. 39:689-711.

Ravallion, M. 2010. Mashup indices of development. Policy Research Working Paper No: 5432. The World Bank. Washington, DC. Available online with updates at http://documents.worldbank.org/curated/en/4547914683 29342000/Mashup-indices-of-development

Ravallion, M. 2011. On multidimensional indices of poverty. J. Econ. Inequal. 9:235-248.

Rendtel, U., L. Rolf and B. Roland. 1998. The Estimation of poverty dynamics using different measurements of household income. Rev. Income Wealth. 44:84-98.

Sen, A. 1985. Well-Being, agency and freedom: The Dewey lectures. J. Phil. 82:169-221.

Sen, A. 2000. Development as Freedom, $1^{\text {st }}$ Ed. Anchor Books. New York, USA.

Streeten, P., S.J. Burki, M.U. Haq, N. Hicks and F. Stewart. 1981. First Things First: Meeting Basic Human Needs in Developing Countries, $1^{\text {st }}$ Ed. Oxford University Press, Washington, D.C., USA.

Sullivan, C. 2006. Do investments and policy interventions reach the poorest of the poor? In: P.P. Rogers, L.M. Ramon, L. Martinez-Cortina (eds.), Water Crisis: Myth or Reality? Taylor \& Francis. London, UK. pp.221-231.

Sumner, A. 2004. Economic well-being and non-economic well-being. UNU-WIDER Research Paper 2004/030. Helsinki. Available online with updates at https://www.wider.unu.edu/sites/default/files/rp2004030.pdf

Thorbecke, E. 2008. Multidimensional poverty: conceptual and measurement issues. In: N. Kakwani and J. Silber (eds.), The Many Dimensions of Poverty. Palgrave MacMillan, New York, USA. pp.3-19.

TURKSTAT (Turkish Statistical Institute). 2008. Tuketim harcamalari, yoksulluk ve gelir dagilimi sorularla resmi istatistik dizisi-6. Available online with updates at www.tuik.gov.tr/IcerikGetir.do?istab_id=156

TURKSTAT (Turkish Statistical Institute). 2014. Income and living conditions survey, 2013. Available online with updates

at http://www.tuik.gov.tr/PreHaberBultenleri.do?id=16083

TURKSTAT (Turkish Statistical Institute). 2015. Income and living conditions survey, 2014. Available online with updates 
http://www.turkstat.gov.tr/PreHaberBultenleri.do?id=18 633.

TURKSTAT (Turkish Statistical Institute). 2016. Address based population registration system. Available online with updates

http://www.turkstat.gov.tr/PreTablo.do?alt_id=1059.

Tsui, K. 2002. Multidimensional poverty indices. Soc. Choice Welfare 19:69-93.

UN. 2016. Sustainable development goals. Available online with updates at

http://www.un.org/sustainabledevelopment/.
UNDP. 2016. United Nations Development Programme, Human Development Reports. Available online with updates http://hdr.undp.org/en/content/multidimensionalpoverty-index-mpi.

Vyass, S. and L. Kumaranayake. 2006. Constructing socioeconomic status indexes: How to use principal component analysis. Health Policy Plan 21:459-468. 